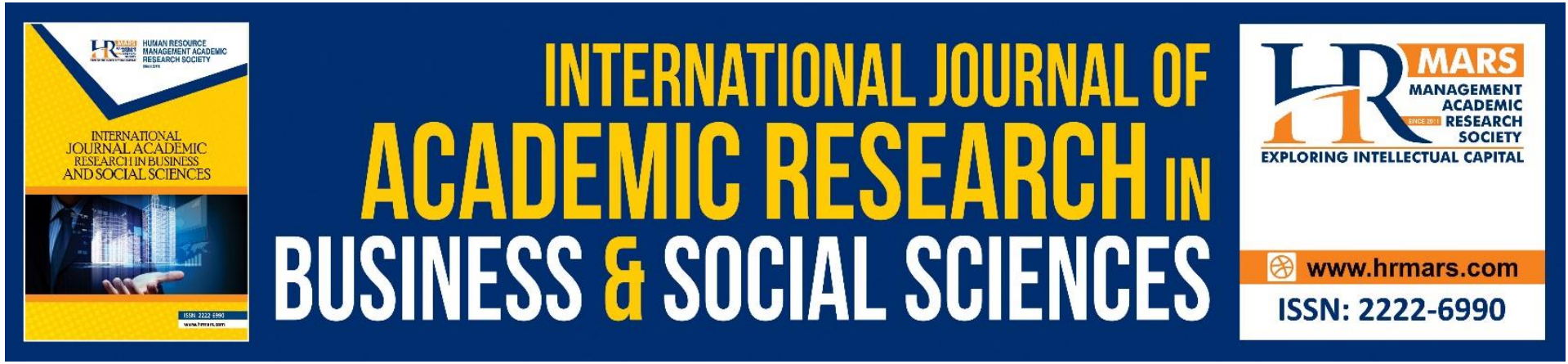

\title{
Sustainable Tourism Through Implementation of the Language Interactive Skills Module Among Local Entrepreneurs at Tuba Island: Module Development Phase
}

Mohd Nor Mamat, Hanifah Musa, Zulaipa Ruzulan, Munirah Azrae, Azlina Kamaruddin

To Link this Article: http://dx.doi.org/10.6007/IJARBSS/v11-i6/10335 DOI:10.6007/IJARBSS/v11-i6/10335

Received: 18 April 2021, Revised: 20 May 2021, Accepted: 08 June 2021

Published Online: 22 June 2021

In-Text Citation: (Mamat et al., 2021)

To Cite this Article: Mamat, M. N., Musa, H., Ruzulan, Z., Azrae, M., \& Kamaruddin, A. (2021). Sustainable Tourism Through Implementation of the Language Interactive Skills Module Among Local Entrepreneurs at Tuba Island: Module Development Phase. International Journal of Academic Research in Business and Social Sciences, 11(6), 1251-1256.

\section{Copyright: (c) 2021 The Author(s)}

Published by Human Resource Management Academic Research Society (www.hrmars.com) This article is published under the Creative Commons Attribution (CC BY 4.0) license. Anyone may reproduce, distribute, translate and create derivative works of this article (for both commercial and non-commercial purposes), subject to full attribution to the original publication and authors. The full terms of this license may be seen at: http://creativecommons.org/licences/by/4.0/legalcode

Vol. 11, No. 6, 2021, Pg. 1251 - 1256

Full Terms \& Conditions of access and use can be found at http://hrmars.com/index.php/pages/detail/publication-ethics 


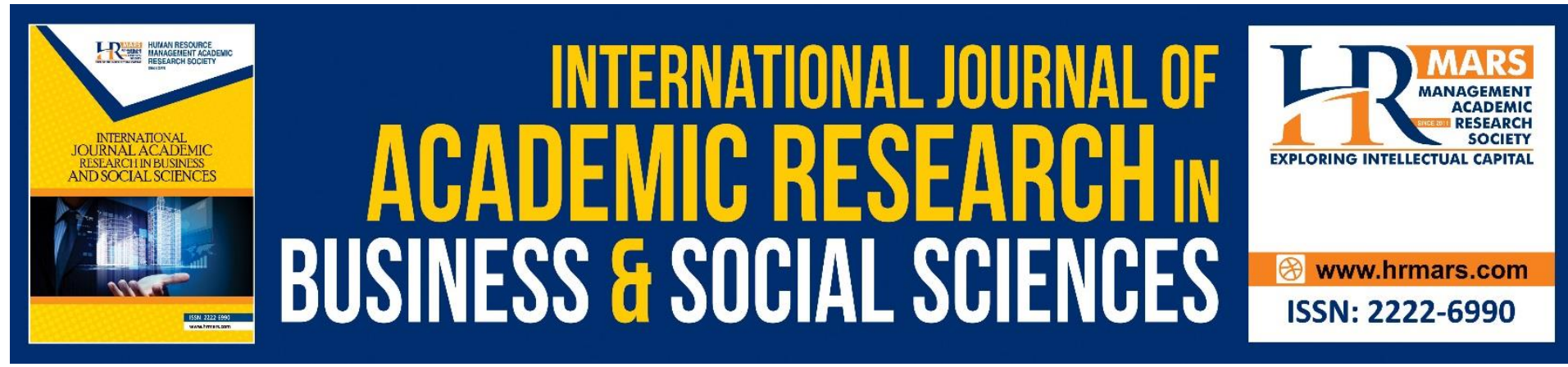

\title{
Sustainable Tourism Through Implementation of the Language Interactive Skills Module Among Local Entrepreneurs at Tuba Island: Module Development Phase
}

\author{
Mohd Nor Mamat ${ }^{1}$, Hanifah Musa ${ }^{1}$, Zulaipa Ruzulan ${ }^{1}$, \\ Munirah Azrae ${ }^{2}$, Azlina Kamaruddin ${ }^{3}$ \\ ${ }^{1}$ Academy of Contemporary Islamic Studies, Universiti Teknologi MARA, Shah Alam, \\ Malaysia, ${ }^{2}$ Academy of Language Studies, Universiti Teknologi MARA, Shah Alam, \\ Malaysia, ${ }^{3}$ School of Multimedia Technology \& Communication, Universiti Utara \\ Malaysia, Malaysia \\ Email:mohdnoor@uitm.edu.my
}

\begin{abstract}
This study focuses on the local community by providing basic language skills guidance as well as increasing confidence in business communication. To achieve this objective, this research is conducted as a 2 in 1 project, namely providing skills training modules for youth entrepreneurs as well as study on the effects of the training on the socio-economic development of the community at Tuba Island. In line with the government's aspirations, few instruments were developed to measure the increase of socio-economic impact as well as the knowledge, skills, attitudes and achievements of the program among the participants.
\end{abstract} Keywords: Tuba Island, Tourism, Sustainable, 3M2U, Language Skills

\section{Introduction}

Tuba Island is the third largest island in Langkawi and inhabited by more than 2,000 locals. Most of the population works as fishermen and farmers, except for a small percentage who work in the tourism industry (Ghazali, Ibrahim, \& Yusoff, 2017). The uniqueness of this island is that it has a geological heritage of national value, which is an important scientific record on the history of the formation of Malaysia. The formation of tropical karst limestone and the granite rock formations that make up Tuba Island embody the beauty of the natural landscape and potentially attract tourists to enjoy it. However, the analysis of the previous studies found that the ecosystem of Tuba Island, which has a small population and limited social and economic networks has caused Tuba Island to be relatively less developed than other islands around Langkawi. On the hand, it is our pride that the island has still maintained its cultural identity and heritage of the Malays. However, few needs to be addressed by the government is how to increase the potential of Tuba Island as a tourist destination while preserving indigenous ownership rights at the same time. Malay customs and culture must be preserved with the development of 
entrepreneurship among the local youth on the island. Thus, researchers see that the $3 \mathrm{M} 2 \mathrm{U}$ method through the mastery of language interactive medium skills is a great way to sustain tourism entrepreneurship activities as well as promote local culture and Tuba Island to the world.

This research is a 2 in 1 project as fulfilling the aspirations of university knowledge transfer services to industry and community (KTP) as well as University for Society (U4S), and at the same time as an experimental research on the training module of Tuba Island's entrepreneurs. The beginning of 2020 saw the implementation of Universiti Untuk Masyarakat (U4S) nationwide inspired by the Minister of Education during the new year message on 14 February 2019 at Universiti Putra Malaysia (UPM). U4S is designed to encourage the transfer of quality knowledge based on scholarship generated in the UA to the needy community to mutual well-being and prosperity. The mission of this initiative is considered an important national agenda by expanding and strengthening the knowledge of the general public by various expertise, learning and skills from the UA. This will have a direct impact on society in the form of changes in knowledge (knowledge), attitudes, skills and life quality. In line with the concept of community development, collaboration of two major initiatives by the Ministry of Education, namely Service Learning Malaysia-U4S (SULAM) which combines the learning objectives of academic courses with community services or networking and Sekolah Ku Universiti Ku (SKUK) initiative. encouraging students and universities to help improve academic development in selected schools according to their respective fields and abilities. The U4S concept involves engaging in the Quadruple Helix model between the public university, government agencies and statutory bodies, relevant industries and key target groups, namely selected communities. Therefore, the implementation in 2020 involves activities in selected communities that will be implemented according to zones.

\section{Methodology}

Interactive communication skills training module for youth entrepreneurs was developed by the experts of language and multimedia communication studies to meet the National Youth Development Policy (Kementerian Belia dan Sukan Malaysia, 2020), linguistics and sociolinguistics skills as well as motivation and leadership skills to fulfil the government aspirations of 3M2U, U4S and University's KTP initiative. Later, the module will be conducted by a research team as speakers / facilitators to 20 selected youths of Tuba Island as case study respondents. The respondents will be selected among most potential entrepreneurs by the local authority of youth entrepreneurs development. This module will be conducted in the form of talks, workshops, LDK and practical activities where the transfer of entrepreneurial skills, self-excellence motivation and language communication knowledge will be done.

On the next phase, respondents will be assessed using pre and post-test methods in structured interviews and questionnaires to measure their understanding of the importance of linguistic skills as an interactive medium in entrepreneurship especially tourism industry, self-confidence level, positive personality and high leadership attitude to build sustainable success while the impact of attitude change in practicing effective interaction skills in career, especially in tourism entrepreneurship will be assessed after 6 months of module run. The result of the research will be evaluated according to the impact on respondent's business achievement as well as language skills, communication skills and leadership development through interview and questionnaire. 


\section{Module Development}

This module was developed with reference to the importance of entrepreneurs in understanding the importance of sociolinguistics as well as enriched linguistic skills to strengthen the sustainability of local tourism activities. The basics of linguistic skills generally include three skills namely listening, reading and speaking. Three major languages are focused on understanding and mastering the basics of interactive communication in Malay, English and Chinese, adjusted to sosio-linguistics skills. This

is in line with the results of several previous studies which found that among the main problems of the success of today's entrepreneurs is lack of skills in problem solving, communication and digital business (Bernama, 2020). The knowledge that is related to sociolinguistics is able to reform more positive and productive entrepreneurs in entrepreneurship, especially in the field of tourism. While the study of sociolinguistics is the descriptive study of the effect of all aspects of society, including cultural norms, expectations and context, the way of language is used, and society's effect on language (Abdullah Yusuf, 2014).

This module is enhanced with elements of self-leadership motivation and entrepreneurial skills to sustain the involvement of local youths in tourism entrepreneurship in Tuba Island. Referring to the National Youth Development Policy (DPBN), among the strategies outlined are knowledge development, attitude formation, skills development and entrepreneurship, as well as fostering a healthy lifestyle, social interaction facilities, partnerships in development and international relations network (Sukan, 2020).

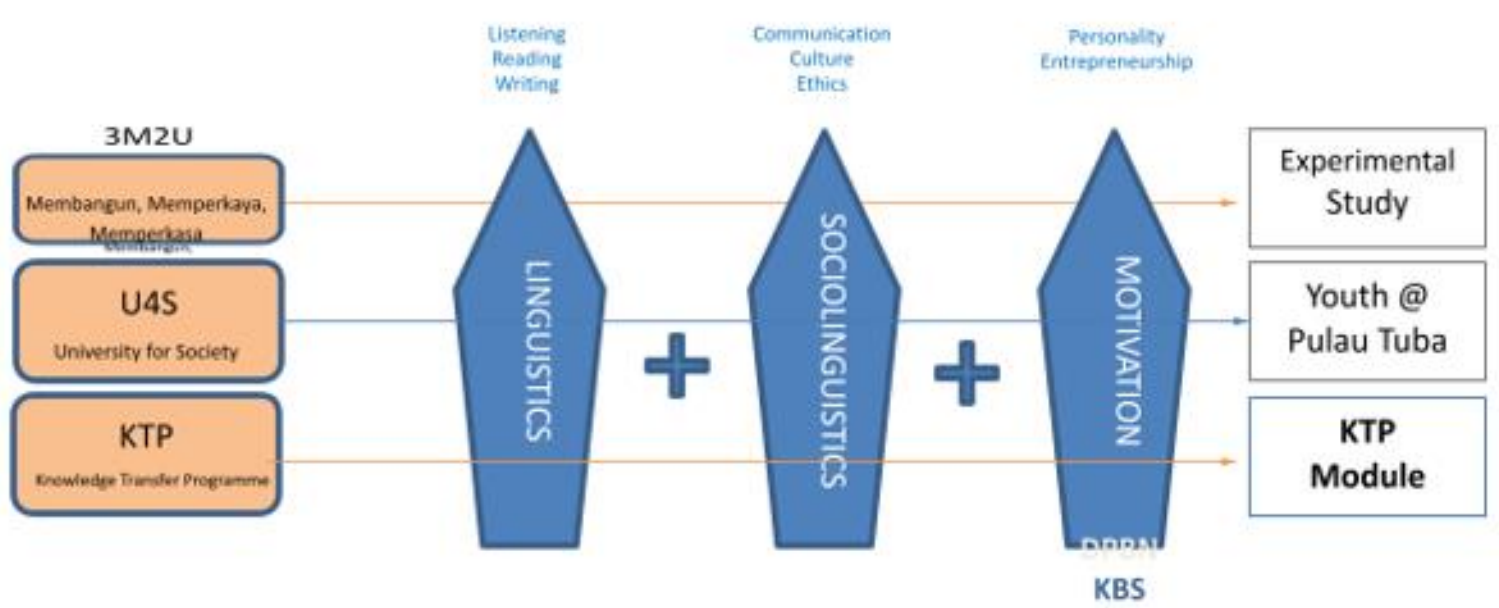

Fig 1. Module Conceptual Development 


\section{Module Proposal}

\section{Module Decsription}

This module contains knowledge and skills transfer on socio-linguistic skills, interpersonal skills, listening-speaking-writing skills, argumentation skills, consulting skills with greeting skills, language register skills and so on. It also focuses on professional linguistic skills based on teamwork, networking, ethical protocols, diplomacy, socio-cultural and others. This course will also share verbal and non-verbal communication skills in communication practice as an effective and productive entrepreneur.

\section{Objectives of the Module}

In parallel of the government aspiration of $3 \mathrm{M} 2 \mathrm{U}, \mathrm{U} 4 \mathrm{~S}$ and the University's initiatives of KTP, this module is designed to achieve these following objectives;

1. Identifying the needs of society especially youth in Tuba Island to promote sustainable tourism.

2. Utilizing $3 \mathrm{M} 2 \mathrm{U}$ through interactive language skills among entrepreneurs and locals as an attraction of Tuba Island for tourists.

3. Implementing $3 \mathrm{M} 2 \mathrm{U}$ through the interactive language skills to enhance and empower youth entrepreneurs of Tuba Island.

\section{Module Outline}

Slot 1 Personality \& Leadership

Slot 2 Interactive Communication Skills in Tourism

Slot 3 Interactive Linguistics Skills in Tourism

Slot 4 Interactive Socio-linguistics Skills in Tourism

Slot 5 Reality Training (Local Product Promotion)

Slot 6 Motivation "Positive and Productive Entrepreneurs"

Duration of the Module: 24 hours

Methods of the Module: Lecture, discussion, presentation and real case study

Assessment: Pre and Post Test, 6 months Post Test

\section{Conclusion}

The module development processes involved the document analysis of National Youth Development Policy, the government's initiatives of $3 \mathrm{M} 2 \mathrm{U}$ and U4S, as well as KTP project by the University. The development processes blended the needed skills to be trained among the youth of Tuba Island, in support of the government mission to promote local places and attractions for tourism. The module is well studied and designed to fix the needs of research objectives, and further study on assessing the effects and impacts towards youth entrepreneurs would be proceeded.

\section{Acknowledgement}

The authors gratefully acknowledge the Universiti Teknologi MARA Malaysia in providing the LESTARI SDG Fund (Project No: 600-RMC/LESTARI SDG-T 5/3 (111/2019) research grant for making this study possible.

\section{References}

Abdullah Yusuf. (2014). Linguistik dan Sosiolinguistik. KL: Open University Malaysia.

Ahmad, M. Z., Ibrahim, J. A., \& Salleh, H. M. (2008). “Membangunkan Kuala Kedah Sebagai 
Destinasi Pelancongan Warisan: Penerapan Konsep Pembangunan Pelancongan Lestari": Persidangan Kebangsaan Ekonomi Malaysia ke III (PERKEM III), Daya Tahan Ekonomi Negara: Dasar dan Strategi Pengukuhan, 20-22 Ogos 2008, Port Dickson: 401413.

BERNAMA. (2020). Pekerjaan Baharu Sektor Pelancongan Perlu Kemahiran Selesai Masalah, Komunikasi dan Digital: Retrieved from https://www.bernama.com/bm/am/news.php?id=1869722 [12 Ogos 2020].

Choy, E. A. (2013). "Pembangunan Pelancongan Lestari di Melaka: Perspektif Pelancong (Sustainable Tourism Development in Malacca: Tourists Perspective)": GeografiaMalaysian Journal of Society and Space, 9 (3): 12-23.

Ghazali, N., Ibrahim, N., \& Yusoff, M. F. M. (2017). "Pembangunan Etos Budaya Etnik Melayu Mengharungi Pemodenan: Kajian Kes di Pulau Tuba Langkawi": Proceedings of the ICECRS, 1 (2016): 1083-1094.

Pondo, H. M. D. H. (2012). Isu Sosiolinguistik di Malaysia. Serdang: Penerbit Universiti Putra Malaysia.

Hassan, F. dan Che Leh, F. (2007). "Pembangunan Pelancongan Lestari di Felda Trolak: Satu Analisis": Prosiding Seminar Geografi-Dunia Tanpa Sempadan, 8-9 September 2007, UPSI.

Bakri, M. H. Y. (2020). "Sektor Pelancongan Main Peranan Penting: Raja Muda Perlis": Utusan Malaysia. Retrieved from https://www.utusan.com.my/nasional/2020/09/kerjasamatingkat-pelancongan perlis/ [1 September 2020]

Kementerian Belia dan Sukan Malaysia. (2020). Dasar Pembangunan Belia Negara. Putrajaya: Kementerian Belia dan Sukan.

Hassan, M. R. (2020). "Hari Belia Malaysia: Apa Perlu Ada dalam Jiwa Anak Muda": Astro Awani. https://www.astroawani.com/berita-malaysia/hari belia-malaysia-apa-perluada-dalam-jiwa-anak-muda-207574 [15 September 2020].

Rashid, R. A., Ismail, R., Rahim, N. A. A., \& Mamat, R. (2017). "Humour and Communication in the Tourism Industry in Malaysia": Jurnal Komunikasi: Malaysian Journal of Communication, Jilid 33(1): 184-198. 